\title{
Brewing tests of new fine aroma hop varieties (Humulus lupulus L.) Saaz Brilliant, Saaz Comfort and Saaz Shine
}

\author{
Alexandr Mikyška*1, Karel Štěrba ${ }^{1}$, Martin Slabý1 ${ }^{1}$, Vladimír Nesvadba ${ }^{2}$, Jitka Charvátová ${ }^{2}$ \\ Research Institute of Brewing and Malting, Lípová 511/15, \\ 12000 Prague, Czech Republic \\ 2 Hop Research Institute, Kadaňská 2525, 43801 Žatec, \\ Czech Republic \\ * corresponding author: mikyska@berresearch.cz
}

\begin{abstract}
Characterization of varietal profiles of hop secondary metabolites in beer is of considerable importance for hop growing and brewing. This three-year study focused on pilot brewing tests of three new Saaz derived hop varieties, namely Saaz Brilliant, Saaz Shine and Saaz Comfort. The sensory profiles of kettle and kettle+dry single hopped beers were monitored. At the same time, the impact of dry hopping technology on sensory perception of final beers and changes in volatile compounds was investigated. Pilot brews $(200 \mathrm{I})$ of $12 \%$ pale lager were prepared in kettle and kettle+dry variants using the new Czech varieties and traditional Saaz as a control sample. Essential oils in beers were determined by GC/MS-MS method with the aim to clarify links to the beer sensory profile of both, kettle and dry hopping mode. The descriptive sensory method of hop-derived aromas and the triangle tests were employed to determine the sensory quality of beer. The overall sensory impression of beers from all tested varieties was at least comparable to traditional Saaz, and Saaz Comfort even reached better evaluation. The profile of essential oils and hop flavours in beer was partially different, however it was not rated worse than Saaz. The kettle+dry hopped beers of new varieties were significantly different from Saaz in the triangle test, Saaz Brilliant was preferred over the Saaz. The results showed considerable potential of new varieties for the production of interesting and taste-specific beers and the enrichment of the spectrum of fine aroma varieties of Czech hops.
\end{abstract}

Key words: hop varieties, beer, hop oils, sensory; kettle hopping, dry hopping; GC-MS-MS

\section{Introduction}

Hops are undoubtedly a brewing raw material, which significantly forms the sensory profile of beer and its popularity by consumers. Approximately 150 hop cultivars have been bred and registered worldwide, and more are being added each year. Breeding a new variety is a process that takes many years. New varieties are bred for many reasons, not least because of the sensory character they give to beer of certain brands. In addition, brewers in the Czech Republic can produce beer with the Protected Geographical Indication (further as PGI) “České pivo" (in translation Czech Beer). However, PGI specification defines a certain proportion of aroma hop varieties with a prescribed resin composition and farnesene content among the essential oils (Commission, 2008).
Hop breeding has a long tradition in the Czech Republic. In 1853 the first clonal selection was performed in the Úštěk growing area by Kryštof Semš from Vrbice near Roudnice, who applied a method of a positive selection. Karel Osvald was the founder of modern methods of hop breeding using clonal selection in original regional stands. He was involved in clone selection from 1927. Thanks to his long-term efforts, the Czech hop industry obtained three clones, which were named after him as Osvald's clone 31, Osvald's clone 72 and Osvald's clone 114 (Fric, 1992). At present, these clones cover $90 \%$ of the total hop growing area in the Czech Republic. In the 1960s, hop hybridization, i.e. crossbreeding, began to 
be used in hop breeding. Bor and Sládek were the first registered Czech varieties after crossbreeding in 1994 (Rígr, 1997). In 1996, a new variety Premiant was registered, which later replaced the variety Bor due to, higher performance parameters. In 2001, the first Czech bitter hop variety (Agnus) was registered, which has an $\alpha$-acids content of $10 \%$ (Krofta et al., 2002). Another 6 hop varieties were registered at the Hop Research Institute in Žatec between the years of 2004 and 2010 (Nesvadba et al., 2013; Nesvadba et al., 2017a), i.e. Harmonie, Rubín, Kazbek, Bohemie, Saaz Late and Vital, the last mentioned variety was bred also for biomedical purposes (Krofta, 2013). Varieties of new generation were registered in 2017. These are two new bitter varieties called Gaia and Boomerang (Nesvadba et al., 2017b). Czech breeding for hop growing on low trellises resulted in registration varieties such as Country, Jazz and Blues in 2018 and 2019 (Nesvadba and Charvátová, 2020).

Hop breeding in the Czech Republic focuses mostly on aroma hops. Czech hops are well known in the world due to the fine aroma variety of "Žatecký poloraný červeňák" (Saaz semi early redbine hops; in short Saaz). The following traits of fine aroma hop varieties are preferred in the breeding - the smell of hop cones, a balanced ratio of $\alpha-/$ $\beta$ - acids, a lower proportion of cohumulone and, above all, a favourable effect on the quality of lager beer. The basis of the breeding of aroma hops is Saaz.

In recent years, foreign varieties or even wild hops have also been used (Nesvadba et al., 2018). A new program was launched in 1995 to create aroma hop varieties, which will be of Saaz origin. This resulted in the registration of three new varieties called Saaz Brilliant, Saaz Comfort and Saaz Shine, which show a number of features identical to Saaz. The Mimosa variety has also been registered under this program, however, its character is completely different. At present, all new varieties are grown in pilot plant conditions and brewing tests and verification brews are also carried out in operational breweries (Nesvadba and Charvátová, 2020a).

The brewing value of hops depends mainly on the content and composition of bitter acids and essential oils. These important brewing substances are formed in the lupulin glands of hop cones (Humulus lupulus L.). Hop resins (bitter acids) give beer its bitterness, while volatile substances from the hop essential oils provide aroma and taste (Almaguer et al., 2014).

Most of the bitterness of beer comes from iso- $\alpha$-acids, isomerized products of $\alpha$-acids (Oladokun et al., 2015; Almaguer et al., 2014; Jaskula et al., 2010). Hulupones, $\beta$-acids oxidation products (Krofta et al., 2019; Algazzali et al., 2016; Dušek et al., 2014) and humulinones, $\alpha$-acids oxidation products (Algazzali et al., 2016), are also bitter.
These oxidation products support the bitterness of dry hopped beers. Moreover, even some polyphenols are bitter or have properties that modify bitterness (Oladokun et al., 2015; McLaughlin et al., 2008).

Bitterness is one of the key attributes used to assess the sensory quality of beer. The sensory bitterness of beer includes various aspects of the bitter impression such as intensity, quality (pleasantness) and its lingering. The perception of organoleptic bitterness is very individual and depends on the beer matrix (He et al., 2014).

The specific aroma that hops impart to beer depends on the technology of hopping used during the brewing process. The composition of hop essential oils mostly responsible for aroma is very diverse, with more than 450 volatile substances that have been identified so far (Inui et al., 2013). Volatile compounds in hops usually represent $0.5-3.0 \%$ by weight (Dresel et al., 2016). Overall, the aroma of the hops results from synergistic effect of the contained components rather than from the impact of a single specific compound.

The components of hop essential oils are generally divided into three chemical groups: hydrocarbons, oxygenated compounds and sulphur compounds. These groups represent $60-80 \%, 20-40 \%$ and less than $1 \%$ of the total essential oils in hops respectively. The main constituents of essential oils are hydrocarbon terpenes, the most common of which are monoterpene myrcene and sesquiterpenes $\beta$-caryophyllene, $\alpha$-humulene, $\beta$-farnesene and selinenes. Oxygenated compounds include alcohols, ketones and esters. The group of terpene alcohols, such as linalool, geraniol, terpineol and farnesol, is essential for the sensory profile of the particular beer.

The essential oils are transformed during brewing process as follows: first, the thermal/oxidative transformation of essential oils takes place during wort boiling. Some components of essential oils are transformed by yeasts during main fermentation (Takoi et al., 2017; Praet et al., 2012) or they get sorbed to the yeast cell surface (typical for myrcene) (Haslbeck et al., 2017). The essential oil components are extracted into a slightly alcoholic solution of young beer during dry hopping. Of course, they are partially sorbed or altered by the present yeasts as well (Forster and Gahr, 2013; Kaltner and Mitter, 2009).

Thus, the wort boiling represents the substantial changes in most components of hop essential oils, which are also accompanied by large losses of these compounds. Only a few polar terpenoids, such as linalool, geraniol and humulene epoxides, can partially survive this process and impart a hop flavour to the final beer (Praet et al., 2016; Kaltner and Mitter, 2009; Fritsch and Schieberle, 2003; Mitter et al., 2001). 
The sensory perception of essential oils in beer are usually described as floral, citrusy, fruity, spicy or herbal aromas. Terpene alcohols, such as linalool and geraniol, are important components of the floral character of hop essential oils and beer. The contribution of hop essential oils is particularly pronounced in dry hopping technique. The typical hoppy taste and aroma of kettle hopped beer is mainly formed by oxidized sesquiterpenes (Praet et al., 2016). It is known that the aroma of raw hops is often not comparable to the hop aroma in the final beer (Hanke et al., 2015; Praet et al., 2012).

The Research Institute of Brewing and Malting (RIBM) performed brewing tests of all new Czech varieties, started with the Bor variety in 1994. This article presents the results of a three-year testing of Saaz Brilliant, Saaz Shine and Saaz Comfort varieties in pilot brewing experiments both in single kettle hopped and kettle+dry hopped brews.

\section{Material and methods}

\subsection{Hop varieties}

The above-mentioned breeding program of fine aroma hop varieties of the Hop Reseach Institute resulted in registration of three new varieties Saaz Brilliant, Saaz Comfort and Saaz Shine, which show numerous features identical to Saaz. The new hop varieties were obtained through crossing of the selected populations of the Saaz semi-early redbine hops (Saaz). The process of selection from the progeny after the "inzucht" crossing of Saaz created Saaz Brilliant. The Saaz Comfort variety was acquired through the selection from the progeny after the parental combination of the developed breeding material, which originates in the Saaz and the Russian variety Serebrjanka. Finally, Saaz Shine was achieved when the selected progeny of Sládek and Saaz varieties were crossed. Tables 1 and 2 show the average contents and compositions of hop resins and essential oils (Nesvadba et al., 2020).

\subsection{Brewing experiments}

Three-year brewing tests with hops obtained from the harvest of 2017 to 2019 were performed in the experimental brewery in RIBM. All malt brews of Czech pale lager from $100 \%$ Pilsner malt were prepared with a double mash decoction procedure.

Hopping with $100 \%$ of the tested hops, or alternatively a comparative hop of the Saaz variety in the amount corresponding to $10 \mathrm{~g} / \mathrm{hl}$ of $\alpha$-acids, was made in three portions: $30 \%$ at the beginning, $50 \%$ after 30 minutes and the last $20 \%$ of hops was added 15 minutes before the end of the 90 minute wort boiling.

The main fermentation took place in cylindroconical tanks with the lager yeast of the RIBM 95 strain. The maximum temperature of the main fermentation was $12{ }^{\circ} \mathrm{C}$. The young beer was cooled down to $5-6{ }^{\circ} \mathrm{C}$ and transferred to lager tanks. The maturation period took 21 days at the temperature of $1-2{ }^{\circ} \mathrm{C}$. Seven days before the end of the maturation, $50 \mathrm{l}$ of beer were removed and dry hopped using a statical process with a dose of $3 \mathrm{~g}$ of tested hops per 1 litter. Consequently, the beers were filtered through a plate filter fitted with depth filter sheets, bottled and pasteurized to $20 \mathrm{PU}$.

\subsection{3 Analyses}

Analyses of hops and beers were performed according to EBC Analytics (Analytica EBC, 2010), including essential oils assessment. Essential oils in beer were measured by a method developed at RIBM (Mikyška et al., 2018). Sensory analysis of beer, including a detailed evaluation of hop aromas, was performed by the inhouse descriptive method and a triangular test of difference. In addition to differentiating one sample, evaluators in a triangular test noted whether they preferred that sample. Sensory assessments were performed by a trained panel of RIBM evaluators.

Table 1 Average content and composition of hop resins for new aroma hop varieties

\begin{tabular}{|l|c|c|c|c|c|}
\hline \multicolumn{1}{|c|}{ Variety } & $\begin{array}{c}\alpha \text {-Acids. } \\
\text { (\% w.) }\end{array}$ & $\begin{array}{c}\beta \text {-Acids. } \\
\text { (\% w.) }\end{array}$ & $\alpha$-/ $\beta$ - Ratio & $\begin{array}{c}\text { Cohumulone } \\
\text { (\% rel.) }\end{array}$ & $\begin{array}{c}\text { Colupulone } \\
\text { (\% rel.) }\end{array}$ \\
\hline Saaz Brilliant & 3.77 & 2.75 & 1.39 & 24.64 & 44.50 \\
\hline Saaz Comfort & 5.59 & 5.67 & 1.02 & 18.04 & 37.17 \\
\hline Saaz Shine & 3.56 & 2.95 & 1.23 & 24.30 & 45.13 \\
\hline
\end{tabular}

Table 2 Average content and composition of hop essential oils for new aroma hop varieties

\begin{tabular}{|l|c|c|c|c|c|c|}
\hline \multicolumn{1}{|c|}{ Variety } & Content (\% w) & Myrcene (\% rel.) & $\begin{array}{c}\beta \text {-Caryophylene } \\
\text { (\% rel.) }\end{array}$ & $\begin{array}{c}\text { trans- } \beta- \\
\text { Farnesene }(\% \\
\text { rel.) }\end{array}$ & $\begin{array}{c}\text { a-Humulene (\% } \\
\text { rel.) }\end{array}$ & Selinens (\% rel.) \\
\hline Saaz Brilliant & $0.3-0.8$ & $11-34$ & $7-14$ & $7-17$ & $14-33$ & $1-9$ \\
\hline Saaz Comfort & $0.4-1,1$ & $14-36$ & $6-12$ & $2-14$ & $10-20$ & $11-26$ \\
\hline Saaz Shine & $0.5-1.3$ & $12-35$ & $7-15$ & $7-20$ & $22-39$ & $<3$ \\
\hline
\end{tabular}




\section{Results and discussion}

\section{Hop samples}

The content of $\alpha$-acids in hop samples used in brewing tests was on average higher in Saaz Comfort than in Saaz. Saaz Brilliant and Saaz Shine cultivars showed comparable results to Saaz (Table 3). The ratio of $\alpha-/ \beta$ acids in the new cultivars was on average lower than or equal to one. It is a characteristic marker of Saaz that the $\alpha-/ \beta$-acids ratio is lower than one. All the three new varieties demonstrated a significant content of $\beta$-farnesene essential oil, i.e. a specific marker of Saaz. The content of polyphenolic substances was lower by about $40-50 \%$ than in Saaz. The profile of secondary metabolites in hop samples corresponded to the profile of the varieties (Tables 1 and 2).

Kettle hopped beers. The values of the basic chemical analysis of beers document the equilibrium of the brews (Table 4). Any influence of the tested cultivars on foaming, colour and other basic parameters of beers was not found. The analytical bitterness of beers ranged between 35-39 IBU. The concentration of total polyphenols in beer was lower for Saaz Brilliant and Saaz Comfort compared to Saaz (246 mg/l). In the case of Saaz Shine, the content of polyphenols was comparable to Saaz.

The spectrum of evaluated essential oils in the beer represented 34 chemical individuals and included monoterpene hydrocarbons ( $\alpha$-pinene, $\beta$-pinene, myrcene, limonene), sesquiterpene hydrocarbons ( $\beta$-caryophyllene, $\beta$-farnesene, $\alpha$-humulene), monoterpene alcohols (linalo- ol, 4- terpineol, $\alpha$-terpineol, cis-geraniol), oxidized sesquiterpenes ( $\beta$-caryophyllene epoxide, farnesol), other hydrocarbons and esters. Essential oils in hops represent a wide range of substances, dominated by terpene hydrocarbons and alcohols. A large part of the essential oils evaporates or is chemically altered already in the course of wort boiling. The conversions and changes in concentration of essential oils continue during fermentation by the biochemical action of the yeast or by the sorption on their surface, which is typical for instance for myrcene (Mikyška et al. 2018; Haslbeck et al., 2017; Praet et al., 2016).

The profile of essential oils in the tested beers shows certain differences of the tested new varieties as well as differences from Saaz. One of the examples can be a higher concentration of linalool in Saaz Comfort and Saaz Shine beers (Table 5). The impact of the concentration and ratio of essential oil components on the sensory character of beer is a complex issue that is still the subject to research (Mikyška et al. 2018; Dresel et al., 2015; Kishimoto et al., 2006).

Table 4 Results of chemical analysis of kettle and kettle + dry hopped beers

\begin{tabular}{|l|c|c|c|c|c|c|c|c|c|}
\hline \multirow{2}{*}{ Parameter / Unit } & \multicolumn{4}{|c|}{ Kettle } & \multicolumn{4}{c|}{ Kettle+Dry } \\
\cline { 3 - 11 } & & Saaz & $\begin{array}{c}\text { Saaz } \\
\text { Briliant }\end{array}$ & $\begin{array}{c}\text { Saaz } \\
\text { Comfort }\end{array}$ & $\begin{array}{c}\text { Saaz } \\
\text { Shine }\end{array}$ & Saaz & $\begin{array}{c}\text { Saaz } \\
\text { Briliant }\end{array}$ & $\begin{array}{c}\text { Saaz } \\
\text { Comfort }\end{array}$ & $\begin{array}{c}\text { Saaz } \\
\text { Shine }\end{array}$ \\
\hline Original extract & $\% \mathrm{w} / \mathrm{w}$ & 11.6 & 11.8 & 11.8 & 11.9 & 11.6 & 11.8 & 11.8 & 11.9 \\
\hline $\begin{array}{l}\text { Attenuation } \\
\text { apparent }\end{array}$ & $\%$ & 77.3 & 77.2 & 76.5 & 75.4 & 75.9 & 76.0 & $77.1 \mathrm{a}$ & 75.0 \\
\hline $\mathrm{pH}$ & - & 4.49 & 4.57 & 4.54 & 4.62 & 4.58 & 4.57 & 4.64 & 4.64 \\
\hline Color & $\mathrm{EBC}$ & 11.7 & 11.8 & 11.2 & 11.4 & 11.3 & 12.2 & 11.1 & 11.6 \\
\hline Bitterness & $\mathrm{IBU}$ & 35 & 39 & 36 & 36 & 36 & 41 & 40 & 37 \\
\hline Iso-a-acids & $\mathrm{mg} / \mathrm{l}$ & 34.3 & 35.9 & 32.2 & 34.1 & 34.3 & 34.0 & 32.5 & 32.6 \\
\hline a-Acids & $\mathrm{mg} / \mathrm{l}$ & 1.0 & 2.0 & 1.3 & 1.4 & 1.6 & 2.7 & 1.7 & 1.8 \\
\hline Total polyphenols & $\mathrm{mg} / \mathrm{l}$ & 246 & 199 & 177 & 231 & 266 & 206 & 193 & 210 \\
\hline
\end{tabular}

Kettle - Single kettle hopped beer; Kettle+Dry - Single kettle and dry hopped beer 
Table 5 Concentration of essential oils in kettle and kettle + dry hopped beers $(\mu \mathrm{g} / \mathrm{l})$

\begin{tabular}{|c|c|c|c|c|c|c|c|c|}
\hline \multirow{2}{*}{$\begin{array}{l}\text { Essential oils } \\
\qquad(\mu \mathrm{g} / \mathrm{l})\end{array}$} & \multicolumn{4}{|c|}{ Kettle } & \multicolumn{4}{|c|}{ Kettle+Dry } \\
\hline & Saaz & $\begin{array}{l}\text { Saaz } \\
\text { Briliant }\end{array}$ & $\begin{array}{l}\text { Saaz } \\
\text { Comfort }\end{array}$ & Saaz Shine & Saaz & $\begin{array}{l}\text { Saaz } \\
\text { Briliant }\end{array}$ & $\begin{array}{c}\text { Saaz } \\
\text { Comfort }\end{array}$ & Saaz Shine \\
\hline a-Pinene & 1.56 & 1.92 & 1.75 & 1.46 & 1.55 & 1.54 & 1.81 & 1.68 \\
\hline Isobutyl isobutyrate & $<1$ & $<1$ & $<1$ & $<1$ & 1.04 & 6.34 & 2.17 & 3.54 \\
\hline$\beta$-Pinene & $<0.5$ & $<0.5$ & $<0.5$ & $<0.5$ & 0.58 & 0.57 & 0.86 & 0.77 \\
\hline Myrcene & 6.43 & 8.67 & 12.27 & 4.76 & 19.27 & 40.75 & 35.75 & 33.39 \\
\hline Methyl hexanoate & $<0.5$ & $<0.5$ & $<0.5$ & $<0.5$ & 0.50 & 0.53 & 0.63 & 0.62 \\
\hline Isoamyl isobutyrate & $<0.5$ & $<0.5$ & $<0.5$ & $<0.5$ & $<1$ & $<1$ & $<1$ & $<1$ \\
\hline Limonene & 1.30 & 1.29 & 1.08 & 0.80 & 1.45 & 2.77 & 1.70 & 1.17 \\
\hline$\beta$-trans-Ocimene & 1.22 & 1.53 & 1.00 & 1.00 & 1.43 & 3.63 & 1.25 & 1.00 \\
\hline 3-Caren & $<1$ & 1.24 & $<1$ & $<1$ & 1.28 & 4.47 & 1.20 & 1.00 \\
\hline Methyl heptanoate & 0.63 & 0.60 & 0.56 & 0.52 & 0.74 & 1.21 & 1.53 & 1.07 \\
\hline Allo-ocimene & 3.35 & 5.33 & $<1$ & $<1$ & 3.05 & 9.83 & 2.13 & 2.48 \\
\hline 2-Nonanone & 1.44 & $<1$ & $<1$ & $<1$ & 2.58 & 2.59 & 6.91 & 2.54 \\
\hline Methyl octanoate & $<1$ & $<1$ & $<1$ & $<1$ & $<0.5$ & $<0.5$ & $<0.5$ & $<0.5$ \\
\hline Methyl nonanoate & $<1$ & $<1$ & $<1$ & $<1$ & $<0.5$ & $<0.5$ & $<0.5$ & $<0.5$ \\
\hline 2-Decanone & $<1$ & $<1$ & $<1$ & $<1$ & 1.88 & 1.70 & 2.89 & 1.22 \\
\hline Linalool & 27.98 & 21.07 & 40.37 & 40.03 & 46.57 & 53.27 & 147.82 & 124.86 \\
\hline Methyl decanoate & $<1$ & $<1$ & $<1$ & $<1$ & $<0.5$ & $<0.5$ & $<0.5$ & $<0.5$ \\
\hline 2-Undecanone & 1.44 & 1.52 & 1.58 & 1.08 & 1.71 & 1.86 & 3.56 & 1.68 \\
\hline$\beta$-Caryophylene & 9.79 & 10.72 & 5.49 & 6.77 & 3.86 & 2.95 & 5.83 & 3.58 \\
\hline 4-Terpineol & 0.92 & 1.06 & 1.21 & 0.99 & 1.23 & 1.77 & 2.22 & 2.22 \\
\hline trans- $\beta$-Farnesene & 2.57 & 2.82 & 2.36 & 4.51 & 2.00 & 3.52 & 2.10 & 3.14 \\
\hline a-Humulene & 1.54 & 3.43 & 5.37 & 8.23 & 2.49 & 4.36 & 2.43 & 4.87 \\
\hline Methyl geranate & $<1$ & 2.75 & 5.85 & 2.76 & 1.13 & 5.30 & 9.88 & 4.94 \\
\hline$a$-Terpineol & 4.23 & 5.18 & 6.80 & 6.86 & 5.03 & 7.96 & 12.35 & 12.41 \\
\hline 2-Dodecanone & $<1$ & $<1$ & $<1$ & 1.09 & $<0.5$ & $<0.5$ & $<0.5$ & $<0.5$ \\
\hline Geranyl acetate & 1.58 & 2.07 & 5.38 & 1.45 & 1.23 & 1.70 & 4.46 & 1.33 \\
\hline cis-geraniol & 12.10 & 10.55 & 4.50 & 4.03 & 10.76 & 14.21 & 8.61 & 9.32 \\
\hline 2-Tridecanone & $<1$ & $<1$ & $<1$ & 1.21 & $<0.5$ & $<0.5$ & $<0.5$ & $<0.5$ \\
\hline a-lonone & $<0.5$ & $<0.5$ & $<0.5$ & $<0.5$ & $<0.5$ & $<0.5$ & $<0.5$ & $<0.5$ \\
\hline$\beta$-lonone & $<0.5$ & $<0.5$ & $<0.5$ & $<0.5$ & $<0.5$ & $<0.5$ & $<0.5$ & $<0.5$ \\
\hline a-Irone & $<0.5$ & $<0.5$ & $<0.5$ & $<0.5$ & $<0.5$ & $<0.5$ & $<0.5$ & $<0.5$ \\
\hline$\beta$-Caryophylene epoxide & 1.91 & 3.52 & 2.53 & 2.04 & 3.17 & 11.69 & 8.00 & 9.24 \\
\hline Farnesol & 81.78 & 73.27 & 46.52 & 30.27 & 41.73 & 52.53 & 53.63 & 31.13 \\
\hline
\end{tabular}

Kettle - Single kettle hopped beer; Kettle+Dry - Single kettle and dry hopped beer

The sensory profiles of hop aromas in the beers prepared from the new cultivars are very similar to those in the control sample prepared from Saaz. Nevertheless, certain differences are apparent, e.g. a higher intensity of floral aroma was found in the beers hopped with Saaz Comfort and Saaz Shine, and a higher resinous and fruity aroma was detected in the Saaz Brilliant and Saaz Shine samples. (Figure 1).

The bitterness of beers was evaluated comprehensively. The values of bitter perception after drinking, culmination of bitterness, lingering and bitterness character of the beers were very balanced. The Saaz hop beers showed a rather finer bitterness compared to the new cultivars. However, the differences are negligible (Table 6).

The overall pleasantness of the hop aroma and the taste of the new cultivars was slightly better in comparison with Saaz. The aroma of Saaz Comfort was undoubtedly evaluated as more pleasant.

The balance, agreement between the fullness, bitterness, sweetness, bitterness and acidity of all beers was equal. In the overall sensory impression, the beers 
Table 6 Results of descriptive sensorial analysis of kettle hopped beers

\begin{tabular}{|c|c|c|c|c|c|c|c|c|}
\hline Kettle & \multicolumn{2}{|c|}{ Saaz } & \multicolumn{2}{|c|}{ Saaz Briliant } & \multicolumn{2}{|c|}{ Saaz Comfort } & \multicolumn{2}{|c|}{ Saaz Shine } \\
\hline Parameter & $\mathbf{R}$ & SD & $\mathbf{R}$ & SD & $\mathbf{R}$ & SD & $\mathbf{R}$ & SD \\
\hline carbonation & 2.7 & 0.2 & 2.6 & 0.2 & 2.3 & 0.6 & 2.5 & 0.3 \\
\hline palate-fulness & 2.8 & 0.1 & 2.7 & 0.1 & 2.7 & 0.1 & 2.8 & 0.1 \\
\hline bitterness & 2.2 & 0.2 & 2.1 & 0.2 & 2.1 & 0.2 & 2.2 & 0.0 \\
\hline bitterness - culmination & 3.6 & 0.1 & 3.5 & 0.2 & 3.4 & 0.1 & 3.6 & 0.1 \\
\hline bitterness-lingering & 2.4 & 0.2 & 2.3 & 0.2 & 2.1 & 0.3 & 2.2 & 0.1 \\
\hline bitterness-character & 3.2 & 0.3 & 2.8 & 0.3 & 2.7 & 0.4 & 2.7 & 0.3 \\
\hline astringency & 1.4 & 0.2 & 1.2 & 0.1 & 1.2 & 0.1 & 1.3 & 0.1 \\
\hline sweetness & 1.4 & 0.2 & 1.3 & 0.0 & 1.3 & 0.1 & 1.4 & 0.1 \\
\hline sourness & 1.5 & 0.1 & 1.6 & 0.2 & 1.7 & 0.1 & 1.8 & 0.2 \\
\hline fruity-esteric & 1.5 & 0.1 & 1.4 & 0.2 & 1.4 & 0.2 & 1.5 & 0.1 \\
\hline hoppy & 1.9 & 0.2 & 1.9 & 0.2 & 1.8 & 0.2 & 2.4 & 0.1 \\
\hline hop aroma (pleasantness) & 3.7 & 0.7 & 3.4 & 0.5 & 2.9 & 0.4 & 2.8 & 0.4 \\
\hline hop flavour (pleasantness) & 3.7 & 0.3 & 3.5 & 0.2 & 3.5 & 0.1 & 3.3 & 0.3 \\
\hline balance & 2.1 & 0.1 & 2.1 & 0.2 & 2.0 & 0.1 & 2.1 & 0.1 \\
\hline overall impression & 3.67 & 0.17 & 3.38 & 0.30 & 3.22 & 0.20 & 3.38 & 0.45 \\
\hline
\end{tabular}

$\mathrm{R}$ - Average; SD - Standard deviation

Descriptors 0 (no perception) - 5 very strong); Overall impression 1-9 (descending scale)

balance 1 (well balanced) - 5 (unbalanced)

hop aroma (pleasantness) - 1 (excellent) - 5 (very bad)

from the new cultivars were evaluated slightly better (3.2 to 3.4 points) compared to the comparative beer (3.7 points), the difference was demonstrable only for Saaz Comfort (Table 6).

The triangle tests demonstrated, that Saaz Comfort hops were distinguished from Saaz in two of the three brews and Saaz Comfort's preferred by most evaluators. Saaz Brilliant and Saaz Shine hops were not distinguished from Saaz (Table 7).
Based on repeated brews, it can be stated that the evaluated new varieties show the character of fine aroma hop varieties with a "noble kettle hop aroma" in beer, both in terms of chemical composition as well as sensory perception of beer. The profiles of bitter perception together with hop-derived aromas are close to the traditional Saaz variety.

Slight differences in certain parameters between Saaz and the new varieties of Saaz Brilliant and Saaz Shine were not reflected in the overall distinguishable

Table 7 Results of triangle tests of kettle and kettle + dry hopped beers

\begin{tabular}{|c|c|c|c|c|c|c|c|c|}
\hline \multirow[b]{3}{*}{ Variety/Year } & \multicolumn{4}{|c|}{ Kettle } & \multicolumn{4}{|c|}{ Kettle+Dry } \\
\hline & \multirow{2}{*}{$\begin{array}{c}\text { Right } \\
\text { response }\end{array}$} & \multicolumn{2}{|c|}{ Saaz is } & \multirow{2}{*}{ Different } & \multirow{2}{*}{$\begin{array}{l}\text { Right } \\
\text { response }\end{array}$} & \multicolumn{2}{|c|}{ Saaz is } & \multirow{2}{*}{ Different } \\
\hline & & Better & Worse & & & Better & Worse & \\
\hline & \multicolumn{4}{|c|}{2020} & \multicolumn{4}{|c|}{2020} \\
\hline Saaz Briliant & $5 / 12$ & 2 & 2 & NO & $8 / 12$ & 2 & 6 & YES* \\
\hline Saaz Comfort & $3 / 12$ & 2 & 1 & NO & $12 / 12$ & 8 & 3 & YES** \\
\hline \multirow[t]{2}{*}{ Saaz Shine } & $5 / 12$ & 2 & 2 & $\mathrm{NO}$ & $9 / 12$ & 3 & 5 & YES $^{* *}$ \\
\hline & \multicolumn{4}{|c|}{2019} & \multicolumn{4}{|c|}{2019} \\
\hline Saaz Briliant & $7 / 12$ & 4 & 2 & $\mathrm{NO}$ & 44538 & 3 & 4 & YES* \\
\hline Saaz Comfort & $9 / 12$ & 1 & 6 & YES** & 44538 & 6 & 3 & YES* \\
\hline \multirow[t]{2}{*}{ Saaz Shine } & $5 / 9$ & 5 & 0 & $\mathrm{NO}$ & 44446 & 4 & 3 & YES $^{* *}$ \\
\hline & \multicolumn{4}{|c|}{2018} & \multicolumn{4}{|c|}{2018} \\
\hline Saaz Briliant & $5 / 9$ & 2 & 2 & NO & $7 / 9$ & 1 & 6 & YES $^{* *}$ \\
\hline Saaz Comfort & $8 / 8$ & 2 & 6 & YES** & $7 / 9$ & 8 & 2 & YES** \\
\hline Saaz Shine & $2 / 8$ & 1 & 1 & NO & $7 / 10$ & 4 & 3 & YES* \\
\hline
\end{tabular}

* Significant at $\mathrm{P}=0.05 ;{ }^{* *}$ Significant at $\mathrm{P}=0.01$ 
sensory profile of the beers. These parameters were: the concentration of individual essential oils in beer, the intensity of hop aromas, and the pleasantness of the overall perception of hop aromas and tastes in beer.

On the other hand, the Saaz Comfort variety reached a significantly better evaluation of the pleasantness of hop aromas and tastes in beer. In two of the three experiments, beers hopped with this cultivar were distinguished in a triangular test at a probability level of $99 \%$, and preferred by virtually all evaluators to the comparative beer hopped with the Saaz variety. This means that all three new cultivars provide beers at least comparable to Saaz. were different from the inter-variety differences found in the dry hopped beers.

The overall sensory impression of the beers produced from the new varieties were comparable to the Saaz hopped beer. The comparison of the overall sensory impression of the kettle hopped beers and the dry hopped beers turned out slightly worse for the dry hopped beers by $0.2-0.5$ points. The only exception was the Saaz control variety.

The dry hopped beers from all three tested varieties were differentiated significantly from Saaz in the triangle tests. The evaluators clearly preferred Saaz Brilliant to

\section{Kettle+dry hopped beer}

The results of the chemical analysis of the dry hopped beers are given in Table 4 . The results indicate a slight trend of increasing bitterness (1-4 IBU), higher $\alpha$-acids $(0.4-0.7 \mathrm{mg} / \mathrm{l})$ and total polyphenols $(7-21 \mathrm{mg} / \mathrm{l})$ compared to the previous kettle hopped beer. All this is in line with the findings concerning changes in the already discussed parameters for dry hopping (Mikyška et al., 2018; Forster and Gahr, 2013).

As expected, there was a marked increase in the main components of terpenic essential oils (myrcene, limonene, linalool, $\alpha$-terpineol, 4-terpineol, cis-geraniol, $\beta$-caryophyllene epoxide) compared to the kettle hopped beers (Table 5).

The sensory bitterness of the dry hopped beers was very balanced with only negligible differences in all monitored attributes that are: the bitter perception after drinking, the culmination of bitterness, lingering and the character of bitterness. The Saaz dry hopped beer showed a finer character of bitterness than the kettle hopped beer. The pleasantness of the hop aroma and taste was evaluated slightly better in the dry hopped beers made from Saaz and Saaz Comfort compared to the corresponding kettle hopped beers (Table 8).

Clear differences were found in the hop aroma profiles of all new varieties in the dry hopped beers in comparison with the profile of Saaz hops. The described grassy and resinous aroma was characterized as more intensive. The differences were detected also in the case of hoppy and citrusy aromas (Figure 2).

The profiles of hop aromas and tastes of the dry hopped beers differed substantially from the profiles of kettle hopped beers. The inter-variety differences in the profiles of hop aromas and tastes in the kettle hopped beers

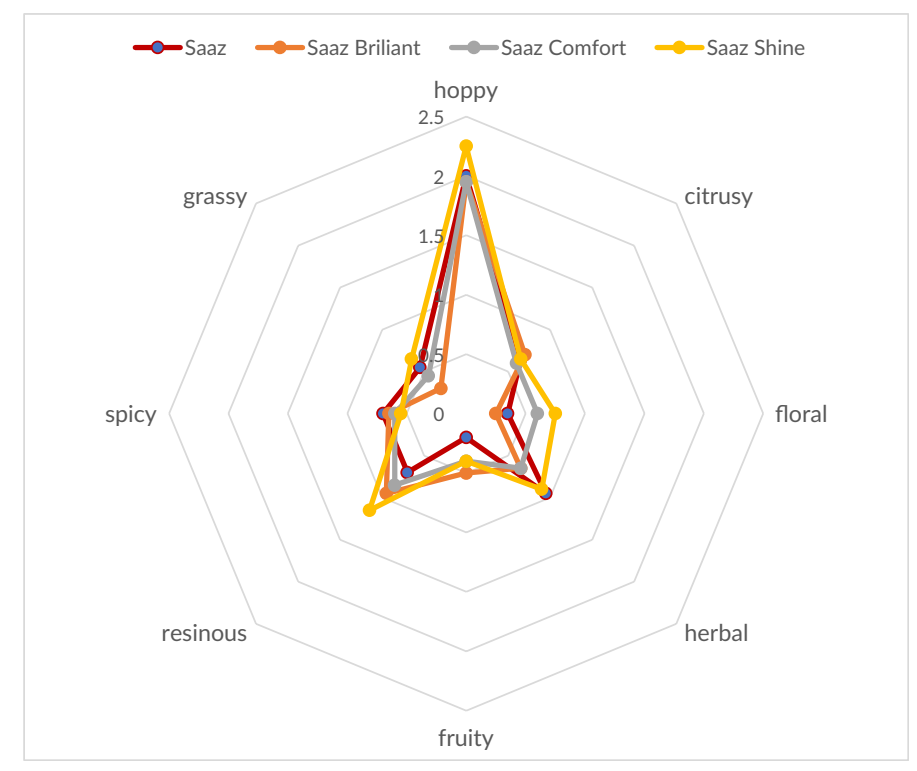

Figure 1 Hop aromas profile in kettle hopped beer Deskriptors scale of 0-5

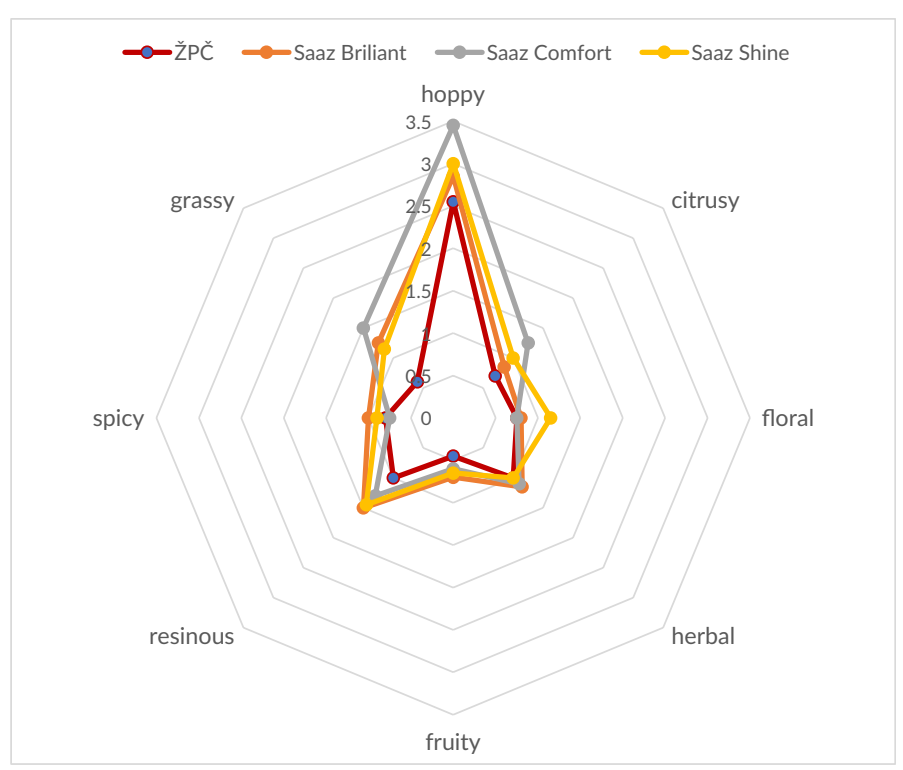

Figure 2 Hop aromas profile in kettle+dry hopped beer Deskriptors scale of $0-5$ 
Table 8 Results of descriptive sensorial analysis of kettle + dry hopped beers

\begin{tabular}{|c|c|c|c|c|c|c|c|c|}
\hline \multirow[t]{2}{*}{ Kettle+dry } & \multicolumn{2}{|c|}{ Saaz } & \multicolumn{2}{|c|}{ Saaz Briliant } & \multicolumn{2}{|c|}{ Saaz Comfort } & \multicolumn{2}{|c|}{ Saaz Shine } \\
\hline & $\mathbf{R}$ & SD & $\mathbf{R}$ & SD & $\mathbf{R}$ & SD & $\mathbf{R}$ & SD \\
\hline carbonation & 2.5 & 0.3 & 2.2 & 0.3 & 2.4 & 0.2 & 2.3 & 0.1 \\
\hline palate-fulness & 2.8 & 0.1 & 2.8 & 0.1 & 2.8 & 0.0 & 2.9 & 0.1 \\
\hline bitterness & 2.3 & 0.1 & 2.0 & 0.1 & 2.3 & 0.2 & 2.3 & 0.1 \\
\hline bitterness - culmination & 3.5 & 0.2 & 3.3 & 0.2 & 3.5 & 0.2 & 3.5 & 0.3 \\
\hline bitterness-lingering & 2.3 & 0.1 & 2.1 & 0.2 & 2.2 & 0.2 & 2.3 & 0.4 \\
\hline bitterness-character & 2.8 & 0.3 & 2.7 & 0.4 & 2.8 & 0.3 & 2.8 & 0.3 \\
\hline astringency & 1.3 & 0.1 & 1.2 & 0.1 & 1.2 & 0.1 & 1.3 & 0.1 \\
\hline sweetness & 1.4 & 0.1 & 1.5 & 0.2 & 1.5 & 0.2 & 1.4 & 0.2 \\
\hline sourness & 1.5 & 0.1 & 1.3 & 0.1 & 1.5 & 0.1 & 1.4 & 0.1 \\
\hline fruity-esteric & 1.6 & 0.3 & 1.4 & 0.3 & 1.6 & 0.2 & 1.8 & 0.3 \\
\hline hoppy & 2.4 & 0.2 & 2.7 & 0.2 & 3.1 & 0.3 & 3.0 & 0.4 \\
\hline hop aroma (pleasantness) & 3.2 & 0.6 & 3.5 & 0.4 & 2.5 & 0.3 & 2.9 & 0.4 \\
\hline hop flavour (pleasantness) & 3.1 & 0.2 & 3.6 & 0.5 & 2.8 & 0.0 & 3.7 & 0.3 \\
\hline balance & 2.2 & 0.1 & 2.2 & 0.3 & 2.0 & 0.2 & 2.2 & 0.2 \\
\hline overall impression & 3.55 & 0.40 & 3.87 & 0.66 & 3.39 & 0.43 & 3.79 & 0.29 \\
\hline
\end{tabular}

the comparative Saaz, while Saaz Comfort had lower preferences than Saaz (Table 7).

The fine aroma cultivars Saaz Brilliant, Saaz Comfort and Saaz Shine are intended primarily for second and late hopping. It is obvious that the chemical profile of sensory active substances, i.e. essential oils, and their impact on the intensity and overall sensory perception of single-variety dry hopped beers differ in from each other and also compared to traditional Saaz. In the triangle test, all experimental beers were clearly distinguished from comparative beers at the level of probability of $95 \%$ and higher. Given the evaluators' preferences, it can be assumed that the dry hopped Saaz Brilliant beers are likely to be accepted by consumers better than Saaz and the Saaz Shine and conversely Saaz Comfort beers will not be so well accepted as comparative beers. It can be concluded, based on the results of the kettle hopped beers compared to the dry hopped beers, that the Saaz Comfort cultivar can be more successful for kettle hopping and, on the contrary, Saaz Brilliant for single-variety dry hopping.

\section{Conclusion}

The cultivars of the fine aroma hops of Saaz Brilliant, Comfort and Saaz Shine, registered in the Czech Republic in December 2019, proved to be of excellent quality in repeated pilot brewing tests of the single-variety kettle and kettle+dry hopped pale lager beers. The kettle hopped Saaz Briliant and Saaz Shine beers were fully comparable to the traditional Saaz from the point of sensory evalu- ation, and the Saaz Comfort beers were even better rated than Saaz. The single-variety dry hopped beers were comparable to Saaz in terms of their sensorial quality, i.e. popularity and overall impression. The Saaz Brilliant cultivar was even preferred over Saaz in this regard. The obtained results demonstrated that the new cultivars are not copies of the traditional Saaz, especially when essential oils and the subsequent beer aroma are considered. The composition of hop acids and essential oils together with the sensory profile of these new cultivars also meet the requirements of the Protected Geographical Indication "České pivo". Therefore in 2020 they were included in the list of varieties recommended for Czech beer production. The results of our pilot experiments indicated the considerable potential of all the tested cultivars for the production of interesting and flavour-specific beers as well as the enrichment of the sensory spectrum of traditional Czech beer.

\section{Acknowledgement}

The study was supported by the Ministry of Agriculture of the Czech Republic within the institutional support MZe-R01920 and MZE-R01320. 


\section{References}

Algazzali, V., Shellhammer, T. (2016). Bitterness Intensity of oxidized hop acids: Humuli-nones and hulupones. Journal of the American Society of Brewing Chemists, 74(1), 36-43. https://doi.org/10.1094/ASBCJ-2016-1130-01

Almaguer, C., Schönberger, C., Gastl, M., Arendt, E.K., Becker, T. (2014). Humulus lupulus: A story that begs to be told. A review. Journal of the Institute of Brewing, 120, 289-314. https://doi.org/10.1002/jib.160

Analytica EBC (2010). European Brewery Convention, Carl-Hans Verlag, Nürenberg, 2010. ISBN 978-3-418-00759-5

Commission (2008). Official Journal of the European Union, C016, 23/01/2008, 0014-0022.

Dresel, M., Vogt, C., Dunkel, A., Hofmann, T. (2016). The bitter chemodiversity of hops (Humulus lupulus L.). Journal of Agricultural and Food Chemistry, 64: 7789-7799. https://doi.org/10.1021/acs. jafc.6b03933

Dresel, M., Praet, T., Van Opstaele, F., Van Holle, A., Naudts, D., De Keukeleire, D., De Cooman, L., Aerts, G. (2015). Comparison of the analytical profiles of volatiles in single-hopped worts and beers as a function of the hop variety. Brewing Science, 68 (1/2), 8-28.

Dušek, M., Olšovská, J., Krofta, K., Jurková, M., Mikyška, A. (2014). Qualitative determination of $\beta$ acids and their transformation products in beer and hop using HR/AM-LC-MS/MS. Journal of Agricultural and Food Chemistry, 62, 7690-7697. https://doi.org/10.1021/ jf501852r

Forster, A., Gahr, A. (2013). On the fate of certain hop substances during dry hopping. Brewing Science, 66 (7/8), 93-103.

Fric, V. (1992). Odrůdová skladba a ozdravovací proces chmele v ČSFR (Varietal composition and healing process of hops in the CSFR), Chmelařství, 65, 85-86. Available only in Czech.

Fritsch, H.T., Schieberle, P. (2003). Changes in key aroma compounds during boiling of unhopped and hopped wort. Proceedings of the 29th Congress of European Brewery Convention, Dublin, 2003, Fachverlag Hans Carl, Nürnberg, Germany, CD-ROM.

Hanke, S., Schüll, F., Seigner, E., Engelhard, B., Lutz, A. (2015) Systematic brewing trials for evaluation and selection of new German hop breeding lines and future hop varieties. Proceedings of the 35th Congress of European Brewery Convention, Porto, 24-28 May 2015, 382-399. ISBN 9781510817104

Haslbeck, K., Bub, S., Schönberger, C., Zarnkow, M., Jacob, F., Coelhan, M. (2017). On the fate of $\beta$-myrcene during fermentation - The role of stripping and uptake of hop oil components by brewer's yeast in dry-hopped wort and beer. Brewing Science, 70 (11/12), 159-169. https://doi.org/10.23763/BrSc17-16haslbeck

He, Y., Dong, J., Yin. H., Zhao, Y., Chen, R., Wan, X., Chen, P., Hou, X., Liu, J., Chen L. (2014). Wort composition and its impact on the flavour-active higher alcohol and ester formation of beer: A review. Journal of the Institute of Brewing, 120, 157-163. https://doi.org/10.1002/jib.145

Inui, T., Tsuchiya, F., Ishimaru, M., Oka, K., Komura, H. (2013). Different beers with different hops. Relevant compounds for their aroma characteristics. Journal of Agricultural and Food Chemistry, 61, 4758-4764. https://doi.org/10.1021/jf3053737

Jaskula, B., Aerts, G., De Cooman, L. (2010). Hop $\alpha$-acids isomerization and utilization: An experimental review. Cerevisia, 35, 57-70. https:// doi.org/10.1016/j.cervis.2010.09.004

Kageyama, N., Inui, T., Fukami, H., Komura, H. (2011). Elucidation of chemical structures of the components responsible to beer aftertaste. Journal of the American Society of Brewing Chemists, 69, 255-259. https://doi.org/10.1094/ASBCJ-2011-0901-01

Kaltner, D., Mitter, W. (2009). Changes in hop derived compounds during beer production and ageing. In: Shellhammer, T.H. (Ed.) Hop Flavour and Aroma. Proceedings of the 1st International Brewers Symposium, Master Brewers Association of the Americas, St. Paul, Minnesota, 37-6. ISBN 9780977051984

Kishimoto, T., Wanikawa, A., Kono, K., Shibata, K. (2006). Comparison of the odor-active compounds in unhopped beer and beers hopped with different hop varieties. Journal of Agricultural and Food Chemistry, 54, 8855-8861. https://doi.org/10.1021/jf061342c

Krofta, K., Hervert, J., Mikyška, A., Dušek, M. (2019). Hop beta acids from cones to beer. Acta Horticulturae, 1236, 15-22. https://doi. org/10.17660/ActaHortic.2019.1236.3

Krofta, K., Patzak, J., Nesvadba, V., Mikyška, A., Slabý, M., Čejka, P. (2013). Vital - The Czech hop hybrid variety. Kvasný průmysl, 59(1), 13-17. https://doi.org/10.18832/kp2013001

Krofta, K., Nesvadba, V., Čepička, J., Mikyška, A. (2002). Agnus - první česká vysokoobsažná odrůda chmele. (Agnus-First Czech High-alpha Hop Variety). Kvasny prumysl, 48(9), 239-244. https://doi. org/10.18832/kp2002018

McLaughlin, I.R., Lederer, C., Shellhammer, T.H. (2008). Bitterness-modifying properties of hop polyphenols extracted from spent hop material. Journal of the American Society of Brewing Chemists, 66(3), 174-183. https://doi.org/10.1094/ASBCJ-2008-0619-01

Mikyška, A., Olšovská, J., Slabý, M., Štěrba, K., Čerenak, A., Košir, I. J., Pavlovič, M., Kolenc, Z., Krofta K. (2018). Analytical and sensory profiles of Slovenian and Czech hop genotypes in single hopped beers. Journal of The Institute of Brewing, 124(3), 209-221. https://doi. org/10.1002/jib.494

Mitter, W., Biendl, M., Kaltner, D. (2001). Behavior of hop-derived aroma substances during wort boiling. Proc. EBC Symposium on Flavour and Flavour Stability (EBC Monograph 31), 2001, Nancy, France; Fachverlag Hans Carl, Nürnberg, Germany. ISBN: 978-3-418-00788-5

Nesvadba, V., Brynda, M., Henychová, A., Ježek, J., Kořen, J., Krofta, K., Malířová, I., Patzak ,J., Polončíková, Z., Svoboda, P., Valeš, V., Vostřel, J. (2013). Development and tradition of Czech hop varieties. Chmelařský institut s.r.o. Žatec. ISBN 978-80-87357-11-8.

Nesvadba, V., Charvátová, J (2020). New fine aroma varieties of hops (Humulus lupulus L.) Saaz Brilliant, Saaz Comfort, Saaz Shine and Mimosa. Kvasný průmysl, 66(4), 320-330. https://doi.org/10.18832/ kp2019.66.320

Nesvadba, V., Charvátová, J. (2020a). Nové odrůdy chmele registrované $v$ roce 2019 (New hop varieties registered in 2019). Proceedings of lectures and papers from the seminar Hop Agrotechnics, Žatec 20 February 2020, 163-171. ISBN 978-80-86836-40-9

Nesvadba, V., Charvatova, J., Stefanova, L. (2017a). Hop breeding in the Czech Republic. In: Weihrauch, F. (Ed.) Proceedings of the Scientific-Technical Commission 25-29 June 2017, St. Stefan am Walde, Austria. Wolnzach: Scientific-Technical Commission of the International Hop Growers' Convention, 7-10.

Nesvadba, V., Charvatova J., Stefanova, L. (2017b). New varieties and perspective genotypes of hops. Kvasný průmysl, 63(5), 237-240. https://doi.org/10.18832/kp201724

Nesvadba, V., Charvátová J., Štefanová L. (2018). Využívání genetických zdrojů chmele ve šlechtění (Use of genetic resources of hops in breeding). Chmelařství, 91(4-5), 57-60. Available only in Czech

Oladokun, O., Smart, K., Hort, J., and Cook, D. (2015). Impact of hop bitter acids and polyphenolic profiles on the perceived bitterness of beer. Proceedings of the 35th Congress of European Brewery Convention, Porto, 24-28 May 2015, 538-549. ISBN 9781510817104

Praet, T., Van Opstaele, F., De Causmaecker, B., Aerts, G., De Cooman, L. (2016). Heat-induced changes in the composition of varietal hop essential oils via wort boiling on a laboratory scale. Journal of American Society of Brewing Chemists, 74(3), 212-223. https://doi. org/10.1094/ASBCJ-2016-3257-01 
Praet, T., Van Opstaele, F., Jaskula-Goiris, B., Aerts, G., De Cooman, L. (2012). Biotransformations of hop-derived aroma compounds by Saccharomyces cerevisiae upon fermentation. Cerevisia, 36, 125-132. https://doi.org/10.1016/j.cervis.2011.12.005

Rígr, A., Beránek, F., Nesvadba, V. (1997). Phenotype variability of the main characteristics of hop varieties as a source for hop hybridisation process. Rostlinná výroba, 43(7), 315-318. Available only in Czech.
Takoi, K., Itoga, Y., Koie, K., Takayanagi, J., Kaneko, T., Watanabe, T., Matsumoto, I., Nomu-ra, M. (2017). Systematic analysis of behaviour of hop-derived monoterpene alcohols during fermentation and new classification of geraniol-rich flavour hops. Brewing Science, 70(11/12), 177-186. https://doi.org/10.23763/BrSc17-17takoi 